\title{
Ética na perícia médica
}

\section{Ethical issues concerning medical expertise}

\author{
Marcos de Almeida*
}

\begin{abstract}
Almeida M. Ética na perícia médica. Saúde, Ética \& Justiça. 2008;13(1)37-41.
Resumo: Um juramento de 26 séculos de existência (como o de Hipócrates), seria capaz de abarcar em seus postulados básicos e suas injunções, todos os problemas da medicina atual? A partir dessa indagação inicial (que responde negativamente), o autor, tomando como exemplo a perícia médica (não contemplada pelo sábio de Cós) e a partir da sua proposta para uma reformulação dos preceitos derivada de uma teoria própria da medicina, analisa esse aspecto peculiar da prática médica e caracteriza os seis elementos fundamentais que entende como indispensáveis para o exercício correto e decente dessa atividade, salientando o conhecimento, a lberdade e a isenção para decidir, como os mais importantes.
\end{abstract}

Descritores: Prova pericial. Juramento hipocrático. Prova pericial/ética. Bioética.

T odas as questões de ordem ética que aparecem na medicina atual estão, sem sombra de dúvida, permeadas pelo tema maior da Responsabilidade Médica. E a atitude pericial não foge à regra.

Segundo a mais corrente visão dos Conselhos Profissionais Médicos, voltados ao resguardo ético da Medicina, "a perícia médica é atividade legal, responsável pela produção de prova técnica em procedimentos administrativos e/ou judiciais". Nesta definição usual se encontra a mais profunda vinculação ética da perícia, qual seja, a produção responsável de prova no contexto dos procedimentos referidos. Mas há algumas dúvidas pairando no ar.

A primeira delas surge da indagação da possibilida- de ou não de se estabelecer a responsabilidade em nossos dias, da mesma forma como foi conceituada em Hipócrates. Em outras palavras, será que um código de mais de dois milênios poderá abarcar em seus postulados básicos todas as possibilidades, quase ilimitadas, de uma ciência-arte-profissão que deixou de serapenas (ou quase que somente) paliativa, para se tornar altamente invasora e agressiva?

Só como exemplo, os aspectos da profissão voltados para a coletividade e a ação peculiar dos médicos peritos, teriam, seguramente, de se constituir em novo valor ético, que obrigaria a revisão dos princípios de Hipócrates.

É evidente que a revisão dos pressupostos hipocráticos não se poderia dar de modo abrupto. $\mathrm{O}$

\footnotetext{
* Professor titular de bioética da Universidade Federal de São Paulo - Escola Paulista de Medicina.

EndeREÇO PARA CORRESPondÊnCIA: Marcos de Almeida. Rua Botucatu, 740, Edifício Lemos Torres. São Paulo, SP. CEP 04023-062. E-mail: marcosal01 @ hotmail.com
} 
que estamos querendo dizer é que nestes vinte e cinco séculos a mudança foi demasiado lenta. Os preceitos de Asaph, médico judeu contemporâneo de Galeno, no século II d.c. nada mudaram em 600 anos após Hipócrates. Em pleno período das trevas da humanidade - a Idade Média - tudo andou mais lento ainda. Talvez tenha até havido uma regressão. Salvo por Rhazes e Avicena, livres, geográfica e culturalmente, das garras da Inquisição, as coisas só pioraram.

Nem mesmo as 17 regras de Enjuin, criadas no século XVI na escola médica de Ri-shu, no Japão, escaparam da mesmice, exceto pelo começo, quando Apolo, Asclépios e Higéia e Panacéia foram substituídos por Buhda. Só no século $X X$, com o Código de Ética Médico Americano (1929) é que as coisas começaram a se fazer sentir de modo realmente perceptível. E os códigos começaram a deixar de ser quase que exclusivamente meros códigos de ertiqueta.

Em uma sociedade democrática, moralmente pluralista como a nossa, seria aceito de comum acordo um código de Ética profissional? Haverá obrigações moralmente justificáveis que unam aqueles que professam a arte de curar? Será que certos deveres podem ser estabelecidos como prioritários e independentes das posições particulares que médicos e pacientes possam assumir diante dos dilemas morais específicos da atualidade? Em suma, será possível reconstruir uma moralidade profissional mais adequada às necessidades contemporâneas do que a Ética Hipocrática?

Primeiro surge a erosão gradual da aceitação das fontes tradicionais da moralidade médica. Cada vez menos médicos submetem-se aos fundamentos religiosos da Ética Médica clássica. Menor número ainda pode alegar fidelidade a todas as injunções do Juramento Hipocrático e ao tipo de vida que ele prescreve. Os elementos hieráticos, mágicos e asclépicos que já ligaram os médicos em outras épocas, agora permanecem como simples resíduos.

Consequentemente existe uma ampla divergência de opiniões e valores que caracteriza o debate sobre tantos dilemas morais, como o aborto, a eutanásia, o direito ao cuidado médico, a responsabilidade pericial, a experimentação humana, a pesquisa sobre DNA recombinante, o conceito de início e de fim da vida e muitos mais. As divisões entre médicos, pacientes e público em geral sobre esses temas são marcadas o suficiente para afastar a possibilidade de um grande conjunto de normas homogêneas aceitáveis por todos. Será que não seria de grande valia a participação de todos os envolvidos no ato da cura (e mesmo da sociedade organizada) na elaboração de um código mais justo?

Mesmo os mais antigos códigos carecem de uma origem filosoficamente explícita. Eles se sustentaram, em grande parte, na aplicação à Medicina, de sistemas morais filosóficos, sobretudo teológicos, e não derivaram formalmente de uma verdadeira Teoria da Medicina.

Como resultado, os códigos vigentes são menos universalmente aceitos, mais estreitos nas obrigações exigidas, mais legalísticos e cautelosos em seu aspecto e mais centrados na competência científica do que em considerações humanísticas. Enquanto, por exemplo, estabelecem-se normas e obrigações para proteger as pessoas submetidas à experimentação humana, pouca atenção tem sido dada à responsabilidade social do médico e aos conflitos potenciais desta, face à sua responsabilidade para com o paciente individual.

Segundo nossa visão, duas alternativas parecem existir no momento:

A primeira seria abandonar a possibilidade de um conjunto comum de princípios morais mais altos e retornar à Ética mais simples e menos exigente do artesão. Este era o modelo do médico grego primitivo e que asseguraria, pelo menos, uma promessa de competência e humanismo, capazes de sobreviver até em uma sociedade moralmente pluralista.

A alternativa seria buscar uma remodelação filosófica da ética profissional derivada e inspirada na natureza da própria Medicina e dos atos médicos, bem como de seus inter-relacionamentos no ato da cura.

Nossa proposição tenta aglutinar as duas alternativas: a busca de um fundamento para a moralidade médica (algum tipo de base que possa definir a conduta moral das relações humanas, específica para a atividade médica), porém sem descartar a liberdade para a decisão sobre os dilemas morais peculiares que surgem em alguns casos em particular.

É claro que sempre deve prevalecer o chamado convencimento ético. "Este tipo de convencimento poderá não existir sob a forma de norma positiva, de preceito escrito. Igualmente poderá não decorrer de preceito legal e, até mesmo poder ser entendido como contrário à lei”. Todavia, este é um risco inerente ao exercício da Medicina. É óbvio que não 
se quer significar com isso que o médico deva agir contrariamente à lei; mas apenas salientar que, na ausência de norma legal proibitiva e também na falta de preceito já escrito, deve ele procurar na reflexão bioética o germe da norma que vai guiar a sua conduta.

Não tem muito significado que outros venham a julgá-lo mais tarde de modo diverso ao que ele entendeu ser o seu dever. A grande verdade é que ele não poderia (e nem poderá o médico em qualquer situação) simplesmente suspender a ação e nada fazer, apenas porque não há preceito ético ou legal explícito.

Por outro lado, se a lei é a consagração de um uso ou costume, toda reformulação ética e legal teria de necessariamente originar-se de costumes e práticas novos.

Assim, não há como surgirem preceitos éticos novos sem que novos modos de agir, talvez contrários aos preceitos existentes, venham a questionar a validade e atualidade dos anteriores. Instaura-se, então, um verdadeiro jogo de discreta desatenção aos preceitos e leis prévios, ao mesmo tempo em que aparecem novas formas de conduta. $E$, na medida em que as novas formas revelam melhor sucesso na harmonia entre as pessoas, tendem espontaneamente a apagar a vigência das normas anteriores, até transformarem-se em preceitos novos da ética e mesmo da lei. É a teoria do meta jogo, que está implícita em toda a evolução do Direito, e também na evolução da Ética.

Já dizia Heráclitus, bem antes de Sócrates: "Tanto a Ética, como a Lei, são edifícios em permanente construção. E vão continuar a sê-lo".

O Capítulo XI do Código de Ética Médica, em seu típico sistema de vedações, estabelece:

É vedado ao médico:

Art.118 - Deixar de atuar com absoluta isenção, quando designado para servir como perito ou auditor, assim como ultrapassar os limites de suas atribuições e competência.

Art.119-Assinar laudos periciais ou de verificação médico-legal, quando não o tenha realizado, ou participado pessoalmente do exame.

Art.120 - Ser perito de paciente seu, de pessoa de sua família ou de qualquer pessoa com a qual tenha relações capazes de influir em seu trabalho.

Art.121 - Intervir, quando em função de auditor ou perito, nos atos profissionais de outro médico, ou fazer qualquer apreciação em presença do examinado, reservando suas observações para o relatório.

- A primeira disposição ética restringe a perícia à técnica, nos casos sob análise, aos argumentos científicos próprios da medicina para realizar a finalidade competente, qual seja, a produção da prova documentada em relatório acerca de um evento ou condição passível de constatação e análise médica.

Qualquer outra disposição pericial que não a técnica apropriada, compromete a isenção ética assinalada pelo primeiro artigo regente da atuação moral na perícia.

-A segunda disposição ética diz respeito ao conteúdo autoral ideológico do laudo ou relatório produzido em perícia, vinculando o perito ao documento produzido, mediante sua participação pessoal para a consequente assinatura. Deve haver identidade rigorosa entre laudo e perito.

- A terceira disposição é uma derivação da primeira, ao especificar a impossibilidade de intervenção de vínculos pessoais quaisquer com pessoas envolvidas no rito pericial e que possam, mesmo que só hipoteticamente, caracterizar influência no trabalho a ser realizado.

- A última disposição ética constante do código assinala o caráter documental escrito da prova a ser produzida em perícia, restringindo as manifestações orais acerca dos pareceres conseqüentes do exame técnico realizado, na presença do examinado.

O Conselho Federal de Medicina, na Resolução 1.497/98, considera que os Conselhos Regionais de Medicina têm a incumbência de fiscalizar os atos profissionais do médico designado como perito, este investido da condição de agente público responsável, civil, penal e administrativamente e normatiza:

Art. $1^{\circ}$ - Determinar que o médico nomeado perito execute e cumpra o encargo no prazo que the for determinado, mantendo-se sempre atento às suas responsabilidades ética, administrativa, penal e civil;

Art. $2^{\circ}$ - O médico designado perito pode, todavia, nos termos do artigo 424 do Código de Processo Civil, escusar-se do cargo, alegando motivo legítimo;

Art. $3^{\circ}-\mathrm{O}$ descumprimento da presente Resolução configura infração ética, sujeita à ação disciplinar pelos respectivos Conselhos Regionais de Medicina.

Os Conselhos Regionais de Medicina muitas vezes estabelecem normas específicas no que concerne às perícias médicas, para pontuar e deixar claro as condutas que podem ferir o necessário respeito à ética profissional conducente à regularidade da perícia. 
Como exemplo, é possível citar os CRMs da Bahia e de São Paulo, Resoluções 288/07 e 126/05 alterada pela 167/07, de modo respectivo.

Tais resoluções reformulam vedações relativas à suspeição do perito e aos assistentes técnicos, embora estes não sejam propriamente investidos na condição de agentes públicos, quando houver vínculo de trabalho ou de qualquer outro interesse empresarial, o dever do sigilo, o respeito à autonomia profissional do ato médico e outras.

As resoluções assinalam, ainda, a necessidade de preservação da intimidade do examinando, o direito à obtenção e disponibilidade recíproca de documentos e informações sobre o quanto estiver sob análise pericial e, sobretudo, a preponderância da autonomia científica do perito, que poderá esquivar-se sempre que submetido a qualquer constrangimento, coação ou pressão capaz de influir na imparcialidade técnica necessária.

\section{Preceitos morais na Perícia}

A maioria das profissões repousa na perícia dos seus membros. Os profissionais são profissionais, primariamente, porque sabem, mais do que a imensa maioria, algo de importância e muito relevante para a nossa sociedade. A eles é dado (ou deveria ser dado) poder, respeito, prestígio e salário acima da média. Se são merecedores desse status, isso se deve, em larga medida, ao seu conhecimento especializado e ao modo como eles o usam. Se esses profissionais têm direitos especiais, em contra partida também têm responsabilidades e deveres especiais. Isso primariamente se deve às posições especiais que ocupam no tecido social, tendo em vista seus talentos presumidos. E, secundariamente, aos serviços de caráter único, que prestam à justiça e à comunidade em que vivem. ${ }^{6}$

De modo sistematizado, as recomendações podem ser resumidas em seis, assim distribuídas:

1. Admita sempre, quando você não sabe, quando você só "acha" ou quando sua opinião é apenas mera estimativa. Não superestime a certeza de seu conhecimento ou as inferências que podem, validamente, ser daí retiradas. Recuse dar opiniões quando estiver sendo indagado sobre opiniões que estejam além do alcance de sua perícia. Faça uma distinção precisa entre coisas que ninguém sabe e coisas que você não sabe e faça referências apropriadas nessa última hipótese. Esta pode ser uma máxima difícil para um perito obedecer, desde que o sentimento do seu próprio mérito profissional e também de seu status social, depende de saber mais do que os outros. Alem disso há também o sentimento de frustração em admitir os limites do conhecimento da comunidade que ele representa. Mas é um vício ético fingir saber mais do que você, de fato, sabe, bem como um vício epistêmico acreditar que você sabe mais do que aquilo que você realmente sabe;

2. Dizer a verdade conforme você a vê em seu julgamento profissional, mas sem dar a impressão de que você fala em nome da comunidade de peritos, quando você não o estiver fazendo. Quando a opinião da comunidade de peritos estiver dividida, existe a obrigação de dizer que ela está. Quando sua opinião for o ponto de vista de uma minoria dentro da comunidade de peritos, você deve também deixar isso claro;

3. Nunca aceitar a priori a função de perito. É um grande equívoco aceitar uma perícia sem examinar antes, os elementos disponíveis para formular uma opinião sólida, embasada em fatos concretos. E diga isso com toda clareza a quem Ihe fez a solicitação para atuar como perito. Eventualmente uma análise prévia revelará que sua opinião resultará inócua, ou mesmo contrária ao interesse do solicitador;

4. Reconheça a propensão humana para racionalizar: você poderá ser tentado a acreditar naquilo que os solicitadores dos seus serviços querem ouvir você dizer. Quando possível teste essa tendência checando sua opinião com a de outros peritos confiáveis de sua comunidade, ou mesmo com a opinião de peritos de outras comunidades;

5. Deixe soar mais alto do que quaisquer outras considerações, os imperativos categóricos da consciência moral. Evite posturas que não lhe permitam obedecer a limites morais porque você é suscetível às tentações da posição ou deslumbrado com o brilho midiático. Reconheça que o uso de peritos é dependente de um clima de confiança. Não polua a atmosfera da confiança social, abusando dela para ganho pessoal, inflação de prestígio ou brilhareco profissional;

6. E, finalmente, após uma criteriosa análise, descarte as conclusões irrelevantes, que não levam a lugar nenhum e que só servem para engordar e tumultuar o processo e conduzir o perito a um exercício mental caracterizado pela absoluta inutilidade intelectual e processual. 
Quanto ao capítulo XI do CEM, que se refere especificamente à Perícia Médica, sobressai a sábia regra da absoluta isenção. Não há responsabilidade quando o ato praticado não for livre, deliberado e absolutamente isento.

Sem liberdade, deliberação e isenção, sobram o mando, a imposição e a obediência.
E toda ação mandada, imposta, e obedecida é:

Teologicamenteherética; subversiva da dignidade humana; moralmente injustificada; obscurantista; espiritualmente opressiva.

Não há qualidade moral em um rebanho ao comando do pastor, nem num teatro de mamulengos. Certamente não nas ovelhas nem nos bonecos.

Almeida M. Ethical issues concerning medical expertise. Saúde, Ética \& Justiça. 2008;13(1):37-41.

Авstract: Is a document, 26 centuries old, like the Hipocratic Code, still capable nowadays to decide all the problems that face us due to the new aspects of modern medicine? Starting in this first question (answered by no) the writer, taking as an example the medical expertise (not mentioned- as many other actions- by Hipocrates) and, based in his own proposal, to reformulate the percepts that spring from an actual theory of medicine itself, analyzes the peculiar aspect of medicine expertise and summarizes six basic attitudes, understood as fundamentals to a decent and right way to that function. At the end, emphasizes knowledge, freedom and absence of prejudice as the most important of them all.

KeYwords: Expert testimony. Experty testimony/ethics. Bioethics. Hippocratic oath

Artigo recebido em 22/02/2008.

Aprovado em 14/04/2008.

\section{BiBLIOGRAFIA}

1. Cassel E. Autonomy and ethics in action. $\mathrm{N}$ Engl $\mathrm{J}$ Med 1977; 6:333-4.

2. Dobzhanski T. The biological basis of human freedom New York: Columbia University Press; 1956.

3. Eldenstein L. The professional ethics of the greek physician. In: Temkin O, Temkin CL. Ancient medicine. Baltimore: John Hopkins Press;1967.

4. Gahret CB. The kantian philosophy of space. New
York: Oxford University Press; 1939.

5. Schutzer LVL. Ethica deontologiæ medicæ pressuposita. [Tese de Livre Docência]. São Paulo: Faculdade de Medicina da USP; 1981.

6. Hardwig J. Toward an ethics of expertise. In: Wueste D, editor. Professional ethics and social responsibility. London: Rowman \& Littlefield; 1994.

7. Código de Ética Médica. Brasília CFM.

8. CFM. Resolução 1497/98. 